\title{
MENINGKATKAN PROFESIONALISME GURU SLB MELALUI PENDAMPINGAN PERMAINAN ADAPTIF KETERAMPILAN GERAK DASAR ANAK BERKEBUTUHAN KHUSUS
}

\author{
Febriani Fajar Ekawati ${ }^{1}$, Ismaryati ${ }^{1}$, Tri Winarti Rahayu ${ }^{1}$, Bambang Wijanarko1 \\ ${ }^{\text {I}}$ Fakultas Keolahragaan, Universitas Sebelas Maret, Surakarta, Indonesia \\ * Penulis Korespodensi: febriani@staff.uns.ac.id
}

\begin{abstract}
Abstrak
Dasar pengetahuan dan pemahaman tentang Penjas Adaptif guru PJOK di SLB masih kurang, karena banyak diantara mereka yang berlatar belakang guru kelas. Sehingga kompetensi profesi sebagai guru PJOK kurang terpenuhi. Oleh karena itu, kegiatan pengabdian kepada masyarakat ini bertujuan untuk meningkatkan profesinalisme guru PJOK di SLB Cabang Dinas Wilayah VII melalui pendampingan permainan adaptif keterampilan gerak dasar. Kegiatan ini menggunakan metode pembimbingan berupa peningkatan pemahaman kepada para guru SLB tentang aktivitas fisik yang tepat untuk ABK dan manfaatnya, pelatihan berupa penayangan video pembelajaran permainan adaptif keterampilan gerak dasar untuk anak tunagrahita, dan pendampingan berupa pemantauan dengan memanfaatkan teknologi komunikasi seperti aplikasi whatsapp (WA), video conference (google meet), dan email. Hasil yang diperoleh dalam kegiatan ini adalah kompetensi guru PJOK di SLB Cabang Dinas Wilayah VII dapat dikatakan meningkat, karena mereka semakin menguasai materi permainan adaptif keterampilan gerak dasar. Salah satu indikator kompetensi profesi seorang guru adalah menguasai materi pelajaran selain kompetensi pedagogi, sosial dan kepribadian. Akhirnya, melalui kegiatan ini profesionalisme guru PJOK di SLB Cabang Dinas Wilayah VII bertambah baik.
\end{abstract}

Kata Kunci: penjas adaptif, permainan adaptif, profesionalisme guru PJOK, keterampilan gerak dasar, tunagrahita

\begin{abstract}
The basic knowledge and understanding of adaptive physical education of special schools (SLB) physical education (PE) teachers are insufficient. Most of them are grade teachers who have no background in PE. Therefore, this community service aimed at increasing the professionalism of PE teachers in Cabang Dinas Wilayah VII through adaptive fundamental movement skills mentoring program. There were three methods applied in this program. Firstly, supervising which aimed at increasing physical activity comprehension and its benefits. Secondly, training, which is showing videos of several fundamental movement skill games for students with special needs. Thirdly, mentoring, which is assisting them by utilizing communication technologies such as Whats App, video conference (google meet), and email. The result of this activity revealed that the competency of special school PE teachers in Cabang Dinas Wilayah VII escalated as they increasingly master the adaptive games of fundamental movement skills. One indicator of a teacher's professional competence is to master subject matter other than pedagogical, social and personality competences. Finally, through this activity, the professionalism of special school PE teachers in Cabang Dinas Wilayah VII improved progressively.
\end{abstract}

Keywords: adaptive PE, adaptive games, professionalism of PE teacher, fundamental movement skills, mental retardation

\section{PENDAhuluan}

Slogan Sport for All merupakan bentuk kampanye dunia yang bertujuan untuk mendorong dan memberikan edukasi tentang gaya hidup aktif dan manfaatnya kepada individu dari berbagai tahapan usia dan kondisi fisiknya (TAFISA, 2017) yang di dalamnya termasuk Anak Berkebutuhan Khusus (ABK). ABK adalah anak yang memiliki perbedaan yang signifikan dalam beberapa dimensi dari fungsi kemanusiaannya seperti gangguan secara fisik, mental/ intelektual/ emosional, dan sosial atau indranya mengalami kelainan. Desiningrum, (2016) mendefinisikan ABK sebagai anak yang mempunyai keterbatasan di salah satu atau beberapa kemampuan baik bersifat fisik dan psikologis. Secara fisik, ABK mengalami gangguan antara lain tonus otot yang rendah, kekuatan yang menurun, kontrol postural, dan keseimbangan yang buruk. Salah satu cara untuk mencegah komplikasi 
lebih lanjut, dianjurkan berpartisipasi dalam aktivitas fisik. Tetapi, belum banyak ABK mempunyai kegiatan-kegiatan yang mengarah ke aktivitas fisik. Pada umumnya, kurangnya informasi dan pengetahuan adalah penyebab ABK kurang mendapatkan kesempatan untuk melakukan aktivitas fisik. Kesempatan melakukan aktivitas fisik hanya diperoleh saat mereka di lingkungan sekolah melalui mata pelajaran Pendidikan Jasmani Kesehatan dan Olahraga (PJOK). Namun, masih terdapat beberapa permasalahan yang dihadapi guru-guru Sekolah Luar Biasa (SLB) dalam memberikan materi PJOK ini kepada para ABK di sekolah mereka. Pembelajaran PJOK di SLB hendaknya berupa aktivitas fisik yang mendapatkan penyesuaian atau adaptasi tertentu sesuai dengan kondisi siswanya atau yang biasa disebut dengan Pendidikan Jasmani (Penjas) Adaptif. Tetapi kenyataan di lapangan, sebagian besar guru PJOK di SLB mengajar dengan metode yang sama untuk siswa non ABK. Hal ini disebabkan oleh kurangnya pengetahuan guru-guru tersebut tentang konsep Penjas Adaptif. Menurut Winnick \& Porretta (2017), Penjas adaptif adalah suatu program yang bersifat individu yang berupa kebugaran fisik dan motorik, keterampilan dan pola motorik dasar, keterampilan dalam olahraga akuatik dan tari, serta permainan dan olahraga individu atau kelompok yang dirancang untuk memenuhi kebutuhan unik individu. Lebih lanjut penulis menyebutkan bahwa Penjas Adaptif adalah sub disiplin dari Pendidikan Jasmani yang memberikan pengalaman rasa aman, kepuasan pribadi atas sebuah keberhasilan, dan pengalaman sebuah kesuksesan bagi siswa-siswa dengan berbagai kemampuannya. Dengan demikian, Penjas Adaptif merupakan salah satu bentuk aktivitas yang cocok untuk ABK dalam menerapkan gaya hidup aktif secara fisik, karena dalam penyampaian Penjas Adaptif menekankan aspek keaktifan siswa dan manfaat yang dapat diambil dari aktivitas fisik yang dikerjakan. Sebuah hasil penelitian menyatakan bahwa terdapat hubungan yang signifikan antara kemampuan gerak dasar lokomotor dengan tes kemampuan lari 30 meter (Klavina, Ostrovska, \& Campa, 2017). Temuan tersebut mendukung keyakinan bahwa tingkat keterampilan motorik yang tinggi memberikan kontribusi positif terhadap kinerja aktivitas fisik anak-anak.

Permasalahan dalam mengajar PJOK di SLB juga terjadi pada guru-guru di wilayah Surakarta dan Sukoharjo. Berdasarkan wawancara dengan ketua Musyawarah Kerja Kepala Sekolah (MKKS) Cabang Dinas Wilayah VII, Bapak Drs. Karsono, M. Pd, permasalahan dan kendala yang dihadapi guru-guru SLB tersebut adalah dalam hal kompetensi guru dan fasilitas penunjang pembelajaran PJOK. Guru PJOK di SLB pada umumnya adalah guru kelas yang belum mempunyai dasar pengetahuan dan kemampuan tentang Penjas Adaptif. Lebih lanjut, guru PJOK yang berlatar belakang Pendidikan Jasmani dan Kesehatan belum mempunyai pengetahuan tentang Pendidikan Luar Biasa. Sehingga, kebutuhan guru PJOK yang berkompeten belum terpenuhi. Kompetensi seorang pengajar PJOK di SLB harus seimbang antara pengetahuan dalam bidang Pendidikan Jasmani dan Pendidikan Luar Biasa, agar hasil pembelajaran PJOK pada siswa di SLB benar-benar sesuai dengan kebutuhan siswa. Secara keseluruhan berikut adalah permasalahan yang dihadapi MKKS SLB khususnya Cabang Dinas Wilayah VII dalam pengembangan kompetensi guru khususnya dalam pembelajaran PJOK:

1. Guru PJOK di SLB pada umumnya guru kelas yang belum mempunyai dasar pengetahuan dan kemampuan tentang Penjas Adaptif (aktivitas fisik yang dimodifikasi), sehingga dalam menyampaikan pembelajaran masih belum sesuai kebutuhan ABK.

2. Kurangnya Guru PJOK yang berlatar belakang Pendidikan Jasmani yang juga paham akan Pendidikan luar biasa.

3. Sarana dan prasarana olahraga masih kurang, sehingga perlu memodifikasi aktivitas fisik dan peralatan yang tepat untuk ABK.

4. Masih kurangnya pelatihan atau lokakarya untuk peningkatan kompetensi Penjas Adaptif.

5. Kurangnya pengetahuan guru SLB tentang manfaat dari aktivitas fisik dimana dalam konteks pengabdian ini adalah penerapan permainan adaptif keterampilan gerak dasar yang tepat untuk ABK.

Dari berbagai permasalahan tersebut diatas, maka dalam program pengabdian yang berjudul "Meningkatkan Profesionalisme Guru SLB Melalui Pendampingan Permainan Adaptif Keterampilan Gerak Dasar Anak Berkebutuhan Khusus" diharapkan dapat memecahkan masalah terutama dalam peningkatan kompetensi guru di SLB dalam mengajar PJOK. Selain itu, dengan program ini diharapkan dapat memberikan bekal untuk menjadi terapis saat di luar sekolah. Terapi yang dimaksud adalah terapi dengan menggunakan aktivitas fisik atau terapi gerak. Selanjutnya, dengan mempunyai bekal tersebut guru SLB juga mempunyai tambahan pendapatan di luar sekolah.

Keberadaan FKOR sebagai Fakultas Keolahraagaan di Universitas Sebelas Maret sangat relevan dan dapat memberikan kontribusi dalam hal memberikan pendampingan untuk membuat program aktivitas fisik yang tepat untuk ABK. Tim pengabdi mempunyai pengalaman meneliti dalam bidang aktivitas fisik, Penjas Adaptif, pengukuran dan evaluasi dalam olahraga dan sport massage. Sehingga, dalam merencanakan jenis permainan benar-benar telah melalui analisis dari ahlinya. Dalam program pengabdian ini, tim pengabdi memberikan pelatihan kepada guru PJOK di SLB tentang bagaimana menyampaikan atau mengajarkan permainan keterampilan gerak dasar yang berupa gerak lokomotor, non-lokomotor, dan manipulatif yang lebih menarik untuk siswanya. Tentunya permainan tersebut telah disesuaikan dengan ABK terutama untuk anak tunagrahita, yaitu anak dengan hambatan intelektual yang memiliki kecerdasan di bawah rata-rata, 
mengalami hambatan dalam perkembangan, dan kurang memiliki kemampuan dalam adaptasi perilaku. Karakteristik anak tunagrahita dalam aspek motorik yaitu mempunyai kesulitan melakukan gerak dasar, reaksi gerak sangat lambat, kesulitan dalam merangkai gerak, keseimbangan terganggu, dan khususnya untuk anak Down Syndrome memiliki tegangan otot yang lemah. Kesulitan-kesulitan yang dialami anak tunagrahita tersebut berdampak pada beberapa aspek perkembangan mereka, seperti; kurang maksimal dalam perkembangan bahasanya, kemampuan konsentrasi rendah, kurang memahami konsep sebab akibat, kurang memahami aturan sosial, kurang tanggap dalam menyelesaikan tugas, dan kesulitan dalam memahami instruksi lisan. Dengan memahami karakteristik anak tunagrahita akan mempermudah guru untuk membuat permainan-permainan khususnya dalam materi keterampilan gerak dasar yang cocok untuk mereka. Beberapa hal yang perlu diperhatikan guru dalam membuat permainan-permainan untuk anak tunagrahita adalah pertama instruksi guru harus jelas, tidak terlalu panjang, dan bertahap. Kedua, media yang digunakan harus konkret dan menarik serta dekat dengan kehidupan mereka. Ketiga, jika diperlukan koreksi harus langsung dan berulang. Keempat, penggunaan bahasa hendaknya yang sederhana dan berupa kalimat-kalimat pendek. Kelima, pendampingan dan pengawasan selalu diberikan pada saat proses pembelajaran berlangsung.

\section{BAHAN DAN METODE}

Berdasarkan permasalan yang dihadapi mitra, maka tim pengabdi memberikan solusi dengan beberapa tindakan. Metode dan pendekatan yang digunakan dalam kegiatan pengabdian ini adalah pembimbingan, pelatihan, dan pendampingan. Metode tersebut diuraikan sebagai berikut:

1. Tahap I (pembimbingan): peningkatan pemahaman kepada para guru SLB tentang aktivitas fisik yang tepat untuk ABK dan manfaatnya. Kegiatan tersebut berupa:

a. Pemberian materi tentang permainan adaptif Keterampilan Gerak Dasar (KGD) pada ABK di SLB adalah sebagai salah satu alternatif aktivitas fisik mereka. Materi ini sangat penting disampaikan pada para peserta pendampingan karena fungsi KGD pada $\mathrm{ABK}$ adalah dapat membantu siswa mengembangkan kompetensi dan kepercayaan yang diperlukan untuk memadukan aktivitas fisik secara teratur dalam kehidupan sehari-hari. KGD sering ditampilkan pada saat anak-anak melakukan aktivitas bermain. Keterampilan-keterampilan tersebut mencakup gerakan melempar overhand, menangkap, menendang, menyepak, memukul dengan satu dan dua tangan, memantulkan bola, berlari, menghindar, dan melompat vertikal. Penguasaan keterampilan ini diperlukan oleh siswa jika terjadi perkembangan optimum ke tingkat yang lebih tinggi. Jika siswa kurang menguasai keterampilan tersebut, mereka akan mengalami kesulitan ketika memelajari gerakan-gerakan yang lebih kompleks. Sehingga mengakibatkan anak-anak tersebut akan mengalami kesulitan dalam aktivitasaktivitas olahraga dan selanjutkan akan selalu menolak untuk melakukan aktivitas fisik sebagai bagian dari gaya hidup mereka. Pada kegiatan ini, guru-guru PJOK diberikan penjelasan mengenai pengertian KGD beserta konsep dan kerangka analisisnya. Selain itu, para peserta juga diberikan materi tentang fungsi dan klasifikasi, serta urutan pembelajaran KGD. Selanjutnya, peserta diberikan contoh permainan-permainan untuk mengembangkan kemampuan gerak lokomotor, non-lokomotor, dan manipulatif.

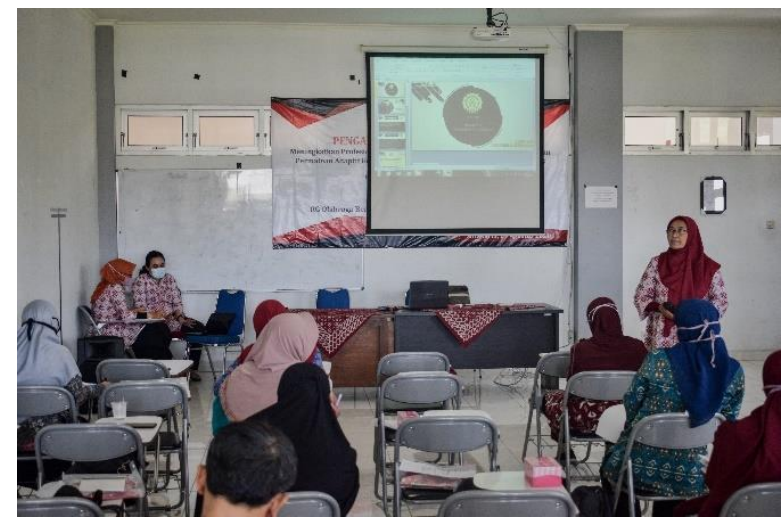

Gambar 1. Penjelasan Materi KGD

b. Pemberian materi tentang manfaat melakukan aktivitas fisik pada ABK. Materi ini perlu disampaikan karena masih banyak ABK dan individu di sekitarnya seperti keluarga dan guruguru di sekolah yang belum memahami manfaat dan hubungan aktivitas fisik ini dengan kesehatan, sehingga; masih banyak diantara mereka yang kurang aktif dan cenderung sedentary. Hal ini mungkin disebabkan oleh kurangnya ketersediaan sarana dan prasarana, kurangnya informasi tentang pedoman melakukan aktivitas fisik untuk mereka, kurangnya dukungan dari masyarakat, dan sifat atau kondisi disabilitas mereka. Sehingga mengakibatkan mereka, khususnya anak tunagrahita, cenderung mempunyai level kebugaran kardiorespiratori daya tahan, dan kekuatan otot yang rendah, dan juga berpengaruh terhadap tingginya angka obesitas diantara mereka (Wouters, Evenhuis, \& Hilgenkamp, 2019). Khususnya untuk anak tunagrahita, manfaat melakukan aktivitas fisik adalah sebagai berikut:

1) Meningkatkan kapasitas erobik. Kapasitas erobik adalah kemampuan tubuh manusia dalam melakukan pekerjaan yang bersifat erobik, yaitu kegiatan yang melibatkan kebutuhan akan oksigen di dalam prosesnya. 
Kapasitas erobik ini ditentukan oleh fungsi jantung dan paruparu, dan juga faktor genetik.

2) Meningkatkan fungsi motorik kasar. Gerakan motorik kasar merupakan kemampuan yang membutuhkan koordinasi sebagian besar otot-otot besar dalam tubuh. Aktivitas yang membutuhkan otot-otot besar dalam pergerakannya adalah gerakan keterampilan non-lokomotor, gerakan lokomotor, dan gerakan manipulatif.

3) Meningkatkan tingkat kepuasan anak atau orangtuanya. Berdasarkan hasil penelitian, aktivitas fisik yang dilakukan oleh anak tunagrahita akan meningkatkan rasa senang dan rasa puas baik untuk anaknya sendiri dan orangtuanya.

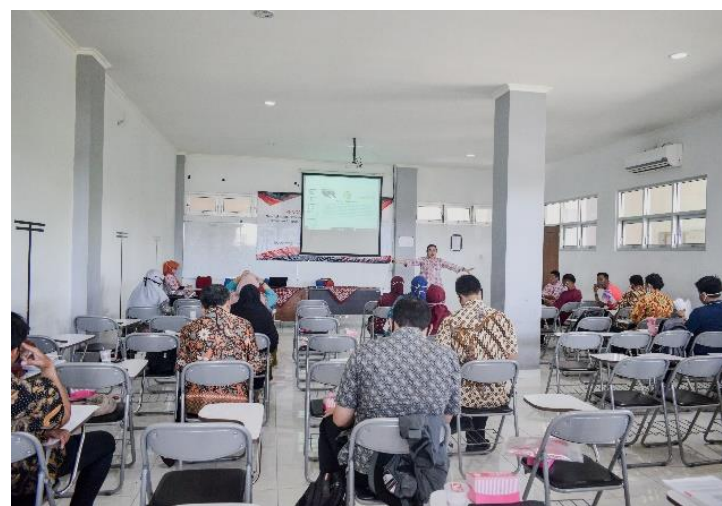

Gambar 2. Penyampaian Materi Aktivitas Fisik

2. Tahap II (pelatihan): praktik permainan-permainan adaptif keterampilan gerak dasar ABK khususnya untuk anak tunagrahita. Karena dalam masa pandemi Covid-19, kegiatan praktik diganti dengan penayangan beberapa video tentang permainan adaptif keterampilan gerak dasar. Kemudian para peserta mengamati serta membuat permainan serupa dengan memperhatikan kondisi sekolah masing-masing. Setelah selesai, mereka menyampaikannya di hadapan kelas dan peserta lain dapat memberikan masukan-masukan. Adapun jenis permainannya adalah sebagai berikut:

a. Keterampilan Gerak Dasar Lokomotor:

1) Permainan musik dan hula hoop: posisi awal anak berada di dalam hula hoop, guru menyalakan musik dan anak keluar hula hoops melakukan gerakan lokomotor sesuai instruksi guru, musik berhenti dan anak berlari masuk hula hoops kembali (sesuai instruksi guru). Tujuan dari permainan ini adalah untuk mengembangkan emosi sosial seperti belajar menguasai diri, belajar bergantian, belajar kompetisi, dan belajar menguasai emosi. Untuk perkembangan kemampuan kognitif berupa fokus, perhatian, dan konsentrasi. Sedangkan untuk faktor fisik, permainan ini bertujuan untuk melatih keseimbangan dan melatih keterampilan gerak dasar lokomotor (lari, berjalan, melompat, meloncat, berjingkat, dll)

2) Berebut bola dari sarang lawan: guru membunyikan peluit sebagai tanda permainan dimulai, pemain dalam tim mulai mengumpulkan telur dari tengah dan menempatkannya di sarang mereka, dalam waktu tertentu, (misalnya 30-45 detik). Saat bagian tengah kosong, mereka diperbolehkan mengambil telur dari sarang/ kelompok lain. Anggota kelompok tidak boleh menghalangi ketika kelompok lain mengambil telur dari sarang mereka; satu poin dikurangkan untuk gangguan. Hanya satu telur yang dapat dibawa dalam satu waktu. Jumlah telur di sarang pada akhir waktu yang dialokasikan adalah skor untuk tim tersebut. Tujuan dari permainan ini adalah untuk mengembangkan emosi sosial yaitu belajar fair play. Untuk perkembangan kemampuan kognitif berupa mengasah kemampuan berpikir cepat. Sedangkan untuk faktor fisik, permainan ini bertujuan untuk berlatih kecepatan reaksi, berlari cepat, dan berlatih berbelok dengan cepat.

b. Keterampilan Gerak Dasar Non-Lokomotor:

1) Seimbang satu kaki: sikap awal adalah berdiri dengan sikap tegak, kedua lengan direntangkan ke samping, salah satu kaki dijulurkan ke belakang, bungkukan badan kedepan sampai posisi badan dan kaki lurus, pandangan tetap ke arah depan,tahan sebentar dan kembali ke sikap semula, dan lakukan bergantian antara kaki kiri dan kanan. Tujuan dari permainan ini adalah untuk mengembangkan emosi sosial yaitu belajar menguasai diri. Untuk perkembangan kemampuan kognitif berupa fokus, perhatian, dan konsentrasi. Sedangkan untuk faktor fisik, permainan ini bertujuan untuk melatih keseimbangan.

2) Bercermin: anak saling berpasangan berhadapan, mintalah seorang anak untuk menjadi "pemimpin" dan melakukan gerakan sederhana di tempat dan pasangannya (anak kedua) untuk meniru pemimpin sebagai cermin refleksi. Misalnya, jika pemimpin melambaikan tangan kanannya, "cermin" melambaikan tangan kirinya dengan cara yang sama, menduplikasi gerakan seolah-olah dia melihat ke cermin. Tujuan dari permainan ini adalah untuk mengembangkan emosi sosial seperti belajar bekerja sama, belajar menerima ide orang lain, dan belajar bergantian. Untuk perkembangan kemampuan kognitif berupa pengembangan sensitivitas visual untuk berubah, melatih fokus, perhatian, dan konsentrasi. Sedangkan untuk faktor fisik, permainan ini bertujuan untuk melatih gerakan-gerakan 
mengembangkan $\begin{array}{rr}\text { non-lokomotor dan juga } \\ \text { kesadaran }\end{array}$ (kesadaran ruang, jarak relatif, dan hubungan dengan ruang-merasakan ruang pribadi).

c. Keterampilan Gerak Dasar Manipulatif:

1) Permainan botol sepuluh: siswa dibagi dalam kelompok-kelompok kecil (5-6 anak) dalam satu kelompok kemudian siswa diminta menggulirkan bola mengenai sasaran (botol) sampai botol roboh secara berurutan sesuai instruksi guru. Tujuan dari permainan ini adalah untuk mengembangkan emosi sosial yaitu belajar kerjasama, menunggu giliran, dan melatih kekompakan kelompok. Untuk perkembangan kemampuan kognitif berupa pengembangan fokus, perhatian, dan konsentrasi. Sedangkan untuk faktor fisik, permainan ini bertujuan untuk berlatih gerakan manipulatif tangan dan mengembangkan kemampuan ketepatan dan akurasi.

2) Permainan menendang bola dengan target: siswa dibagi dalam kelompok-kelompok kecil (5-6 anak) dalam satu kelompok, kemudian siswa diminta untuk menendang bola dengan cara melambung dan masuk ke dalam sasaran (hula hoop), siswa akan memperoleh skor/ nilai jika semua bola ditendang melambung dan dapat masuk sasaran. Tujuan dari permainan ini baik pengembangan emosi sosial, perkembangan kemampuan kognitif dan pengembangan faktor fisik hampir sama dengan permainan botol sepuluh.

3. Tahap III (pendampingan): pendampingan dilaksanakan sebagai tindak lanjut dari kegiatan pengabdian ini. Pendampingan kepada guru-guru SLB di Cabang Dinas Wilayah VII ini berupa konsultasi tentang mengajar PJOK dengan permainan adaptif keterampilan gerak dasar khususnya pada anak tunagrahita. Kegiatan pendampingan dilakukan dengan memanfaatkan teknologi komunikasi seperti aplikasi whatsapp (WA), video conference (google meet), dan email. Mengingat masih dalam masa pandemi Covid-19, penggunaan teknologi komunikasi dipilih sebagai media pendampingan sebagai pengganti kegiatan kunjungan ke sekolah. Tim pengabdi juga memberikan kesempatan kepada para peserta untuk diskusi tentang hal lain yang berkaitan dengan pembelajaran Penjas Adaptif seperti metode, strategi, dan pendekatan yang digunakan untuk mengajar PJOK di SLB.

\section{HASIL DAN PEMBAHASAN}

Program Pengabdian Kepada Masyarakat (PKM) yang dilakukan dalam kegiatan ini adalah pendampingan kepada guru-guru PJOK di SLB Cabang Dinas Wilayah VII untuk mengajar permainan adaptif keterampilan gerak dasar pada anak berkebutuhan khusus. Uraian mengenai hasil kegiatan ini akan disampaikan bersama dengan target yang ingin dicapai. Target pertama yaitu memberikan pemahaman kepada para Guru PJOK SLB tentang konsep Penjas Adaptif dan jenis-jenis gerak dasar yang perlu diajarkan ke para siswa di SLB. Berdasarkan survei yang kami lakukan sebelum acara dimulai, guru PJOK SLB ini belum semua paham tentang mengajar Penjas untuk para siswanya. Umumnya, pedoman mereka mengajar ABK disamakan dengan mengajar anak yang non ABK. Dengan diberikan pemahaman tentang Penjas Adaptif ini, para guru PJOK Cabang Dinas Wilayah VII telah paham bagaimana mengelola kelas mereka dengan prinsip yang benar tentang Penjas untuk ABK. Selain itu, untuk mereka yang mengajar PJOK tetapi dengan latar belakang Guru Kelas juga mulai paham tentang jenis-jenis gerak dasar yang perlu diberikan pada siswanya. Setelah kegiatan ini, mereka semakin paham untuk merancang kegiatan mengajar PJOK berdasar prinsip yang benar yaitu prinsip-prinsip mengajar Penjas Adaptif. Antusiasme para guru dalam penyampaian materi tentang Penjas Adaptif ini sangat besar. Terbukti dari banyaknya pertanyaan-pertanyaan yang disampaikan kepada tim pengabdi pada saat sesi tanya jawab. Untuk kelompok guru dengan latar belakang Pendidikan Jasmani, pada umumnya pertanyaan yang disampaikan meliputi karakteristik anak tunagrahita. Sedangkan pada kelompok guru dengan latar belakang Pendidikan Luar Biasa, sebagian besar pertanyaan mencakup proses mengajar Pendidikan Jasmani. Hal ini dapat disimpulkan bahwa untuk mengajar Penjas Adaptif, guru harus mempunyai pengetahuan tentang dua jenis pengetahuan yaitu pengetahuan tentang Pendidikan Jasmani dan Pendidikan Luar Biasa. Dengan menguasai dua bidang ilmu Pendidikan tersebut, guru PJOK di SLB akan mempunyai kompetensi yang memadahi dalam mengajar Penjas Adaptif.

Target selanjutnya yaitu para peserta memiliki kompetensi dalam mengajar Penjas Adaptif khususnya pada proses mengajar kemampuan gerak dasar yang berupa gerak lokomotor, non-lokomotor, dan manipulatif beserta manfaat yang dapat diambil dari proses permainannya yang berupa: pengembangan emosi sosial, pengembangan kognitif, dan pengembangan fisik. Penyampaian materi ini yang semula direncanakan praktik berubah menjadi menyimak penayangan video-video permainan untuk mengajar KGD. Setiap selesai menayangkan video pembelajaran, misalnya permianan musik dan hula hoop, para peserta diinstruksikan untuk merancang permaianan yang sesuai dengan kondisi di sekolah masing-masing. Hasilnya disampaikan di kelas, dan peserta lain dapat memberikan masukan-masukan untuk permainan yang sudah dibuat. Pada kegiatan ini para peserta aktif untuk membuat kreasi permainan dengan aturan-aturan yang dimodifikasi. Dengan demikian, setelah selesai kegiatan ini, peserta pengabdian kepada masyarakat diharapkan mampu meningkatkan kompetensinya dalam mengajar Penjas 
Adaptif serta memahami manfaat dari materi pembelajaran keterampilan gerak dasar baik dalam aspek kognitif, afektif, dan psikomotor. Setelah paham, mereka dapat mengembangkan kemampuan ini untuk mendasari kemampuan terapi gerak pada ABK. Jika mereka masih mengalami kesulitan setelah dua tahap kegiatan, para guru diperkenankan untuk menghubungi kami tim pengabdi untuk diskusi lebih lanjut.

Pada akhir kegiatan, tim pengabdi melakukan wawancara kepada beberapa peserta pendampingan. Hampir semua peserta mengatakan bahwa banyak manfaat yang diperoleh dari kegiatan pengabdian masyarakat ini, salah satunya adalah mendapatkan bekal pengetahuan untuk mengajar Penjas Adaptif untuk ABK di SLB. Selain itu, para guru PJOK juga semakin menguasai materi khususnya dalam menyampaikan KGD dalam permainan-permainan yang disesuaikan. Contohnya dalam mengajar gerak dasar lokomotor, mereka telah mendapatkan gambaran tentang bagaimana mengombinasikan berbagai gerak lokomotor seperti berlari, berjalan, melompat dan lainlain dalam satu permainan yang lebih menarik perhatian siswa khususnya anak tunagrahita. Untuk gerak dasar non-lokomotor, para peserta semakin kreatif untuk membuat permainan yang lebih interaktif dan menarik, yang semula hanya berupa instruksiinstruksi secara verbal. Untuk mengajar gerak dasar manipulatif, para peserta semakin bertambah wawasannya untuk menggunakan berbagai macam peralatan yang ada di sekitar. Dengan demikian, kompetensi guru PJOK di SLB Cabang Dinas Wilayah VII dapat dikatakan meningkat. Hal ini ditandai dengan penguasaan materi mereka yang semakin baik setelah mengikuti pendampingan. Menguasai materi pelajaran merupakan salah satu indikator kompetensi profesi seorang guru selain kompetensi pedagogi, sosial dan kepribadian. Program pelatihan dan pendampingan kepada guru di sekolah untuk meningkatkan profesionalitas guru seperti yang terdapat dalam UU No. 14 Tahun 2005 tentang Guru dan Dosen hendaknya terus dilakukan sebagai salah satu upaya untuk mendukung program pemerintah (Dewi, Supriyono, \& Saputra, 2020). Selain menguasai materi pengajaran, kemampuan membuat desain pembelajaran menggunakan peta konsep dan kemampuan menulis dalam bentuk artikel ilmiah juga merupakan bagian dari profesionalitas seorang guru (Setiawan \& Syaifuddin, 2020; Sulianto, Muryantobroto, Untari, Budiman, \& Wardana, 2019).

Selain melakukan wawancara pada sebagian peserta, tim PKM juga memberikan angket yang berisi tentang informasi antara lain tentang identitas peserta, lama mengajar, pengalaman mengajar Penjas Adaptif, keikutsertaan dalam pelatihan tentang Penjas Adaptif, kesulitan-kesulitan dalam mengajar Penjas Adaptif, dan harapan dalam mengajar Penjas Adaptif. Pada poin harapan, hampir semua peserta menginginkan panduan yang jelas tentang metode, model, atau pendekatan untuk mengajar Penjas Adaptif sesuai dengan jenis disabilitas pada anak-anak di SLB. Berdasarkan pengalaman mereka yang rata-rata telah mengajar diatas lima tahun, belum ada panduan khusus tentang mengajar Penjas Adaptif ini, sehingga dalam menyampaikan materi di kelas mereka mengajar berdasarkan pengetahuan yang diketahuinya saja. Lebih lanjut, pelatihan atau kegiatan sejenis tentang Penjas Adaptif juga masih sangat jarang. Dari 24 peserta, hampir 80 persen menyataan belum pernah mengikuti pelatihan tentang mengajar Penjas Adaptif.

Kegiatan ini juga mendapatkan apresiasi yang baik dari ketua MKKS Cabang Dinas Wilayah VII karena program peningkatan profesionalitas merupakan salah satu agenda yang sudah direncanakan sebelumnya. Sehingga ketika tim pengabdi menyampaikan gagasan tentang program pendampingan ini pada awal pertemuan disambut dengan baik. Lebih lanjut, beliau berharap kerjasama antara UNS dan MKKS Cabang Dinas Wilayah VII ini akan berlangsung terus.

\section{KESIMPULAN}

Tujuan utama dari pengabdian masyarakat ini adalah untuk meningkatkan profesionalisme guru PJOK di SLB Cabang Dinas Wilayah VII melalui pendampingan mengajar permainan adaptif keterampilan gerak dasar. Setelah kegiatan selesai, para guru semakin bertambah pengetahuannya dalam mengelola kelas PJOK di SLB. Mereka semakin paham tentang prinsip-prinsip dan konsep mengajar Penjas Adaptif, terutama dalam menyampaikan atau mengajar permainan-permainan adaptif keterampilan gerak dasar. Antusiasme para guru PJOK di SLB dalam memahami materi sangat tinggi, mengingat latar belakang mereka banyak yang bukan dari Pendidikan Jasmani dan Kesehatan. Salah satu kelemahan dalam kegiatan ini adalah materi yang pengabdi sampaikan belum mencakup pada semua jenis disabilitas, hanya sebatas pada anak tunagrahita. Dengan demikian, para guru masih perlu mendapatkan pendampingan berkelanjutan tentang Penjas Adaptif ini, karena menurut informasi dari mereka kegiatan serupa sangat jarang diberikan oleh dinas terkait.

Pendampingan pada guru-guru PJOK di SLB untuk meningkatkan kompetensi profesi masih diperlukan dari pihak yang berkompeten dalam hal ini adalah Fakultas Keolahragaan, karena sebagian besar guru PJOK tersebut adalah guru kelas dengan latar belakang Pendidikan Luar Biasa bukan Pendidikan Jasmani dan Kesehatan. Oleh karena itu, kerjasama antara UNS dan pihak mitra akan tetap berjalan untuk melanjutkan kegiatan-kegiatan serupa.

\section{UCAPAN TERIMA KASIH}

Ucapan terima kasih ditujukan kepada ketua MKKS Cabang Dinas Wilayah VII yang telah bekerjasama dan mendukung terlaksananya kegiatan ini. Penulis juga berterima kasih kepada Universitas Sebelas Maret selaku pemberi dana kegiatan kegiatan PKM ini. Nomor Kontrak: 453/UN27.21/PN/2020.

\section{DAFTAR PUSTAKA}


Desiningrum, D. R. (2016). Psikologi Anak Berkebutuhan Khusus (1st ed.). Yogyakarta: Psikosain.

Dewi, N. S. N., Supriyono, Y., \& Saputra, Y. (2020). Pengembangan Media Pembelajaran Bahasa Berbasis Gamifikasi untuk Guru-Guru di Lingkungan Pondok Pesantren Al Amin Sindangkasih-Ciamis. E-Dimas: Jurnal Pengabdian Kepada Masyarakat, 11(3), 382387. dimas.v11i3.5146

Klavina, A., Ostrovska, K., \& Campa, M. (2017). Fundamental movement skill and physical fitness measures in children with disabilities. European Journal of Adapted Physical Activity, 10(1), $28-37$. https://doi.org/10.5507/euj.2017.004

Setiawan, Y. E., \& Syaifuddin, S. (2020). Peningkatan Kompetensi Profesionalitas Guru Melalui Pelatihan Desain Pembelajaran Peta Konsep. Jurnal Pengabdian Kepada Masyarakat, 26(3), 148.

https://doi.org/10.24114/jpkm.v26i3.16377
Sulianto, J., Muryantobroto, M., Untari, M. F. A., Budiman, M. A., \& Wardana, M. Y. S. (2019). Peningkatan Profesionalitas Guru Melalui Karya Tulis Ilmiah Dan Karya Tulis Populer Bagi Kelompok Kerja Guru Kelas Gugus Joko Tingkir Kota Salatiga. Jurnal Pengabdian Kepada Masyarakat, 25(1), 54. https://doi.org/10.24114/jpkm.v25i1.14396

TAFISA. (2017). Mission 2030 Tafisa for a Better World Through Sport for All. Retrieved from http://www.tafisa.org/sites/default/files/pdf/201 8/TAFISA_Mission2030.pdf

Winnick, J. P., \& Porretta, D. L. (Eds.). (2017). Adapted Physical Education and Sport (6th ed.). Champaign, IL: Human Kinetics.

Wouters, M., Evenhuis, H. M., \& Hilgenkamp, T. I. M. (2019). Physical fitness of children and adolescents with moderate to severe intellectual disabilities. Disability and Rehabilitation, $O(0)$, $1-11$. https://doi.org/10.1080/09638288.2019.157393 2 